1 The Family Division of the High Court exercises jurisdiction in family proceedings in England and Wales. A broadly similar jurisdiction is exercised
under the Children Act in care proceedings and in private law disputes between parents by county courts and family proceedings courts. It should between parents by county courts and family proceedings courts. It should
be emphasised that this article is about civil, not criminal, proceedings in be emphasised that this article is about civil, not criminal, proceedings in
which the burden of proof is different and the practice which I describe does not apply.

2 The most recent example is the acknowledgment by the Court of Appeal that paediatricians and child psychiatrists are entitled in family proceedings to express opinions on child abuse which are based on or take into account the expert's assessment of the child's truthfulness: see Re M and R (Child Abuse: Evidence) [1996] 2 FLR 195, CA. Equally, I do not have space to address the duties of experts generally, as to which there is agreement across all the divisions of the High Court that expert evidence presented to the court should be and should be seen to be the independent product of the expert uninflue and should be seen to be the independent product of In Re J [1991] FCR 191 at $226 / 7$. Cazalet J said the exigencies of litigation. In Re J [1991] FCR 191 at 226/7, Cazalet J said that in children's cases the duty to be objective and not to mislead is as vital as in any case, because the child's welfare is at stake, and his/her interests are paramount. He added that an absence of objectivity may result in a child being wrongly placed and thereby unnecessarily at risk. It must also be borne in mind that a misleading opinion from an expert may well inhibit a proper assessment of a particular case by the non-medical professional advisers and may also lead parties, and in particular parents, to false views and hopes.

3 By section 12 of the Administration of Justice Act 1960, as amended by Schedule 13, para 14 of the Children Act 1989, it is a contempt of court to publish information relating to proceedings brought (inter alia) under the Children Act.

4 Oxfordshire County Council v M [1994] Fam 151, CA: Re L (A Minor) (Police Investigation) [1996] 2 WLR 395, HL

5 By section 1(2) the court is required to have regard to the general principle that any delay in determining questions relating to the upbringing of children is likely to prejudice their welfare.

6 Children Act 1989, ss 11 (private law proceedings) and 32 (public law)

7 Family Proceedings Rules, 1991 r.4.18 and 4.23.

8 As HH Judge Wilson put it in Oxfordshire County Council v M [1994] Fam 151 at 158. ' the court is concerned from beginning to end and overwhelmingly with doing everything possible to come to the right conclusion for the future of the child with which the court is concerned. The game of adversarial litigation has no point when one is trying to deal with fragile and vulnerable people like small children. Every other consideration must come second to the need to reach the right conclusion if possible'.

9 Re L (A Minor) (Police Investigation) [1996] 2 WLR 395, HL. Heroin addict parents obtained the leave of the court to show the papers to a consultant chemical pathologist with a view to demonstrating that their 2 year old could have ingested a substantial quantity of methadone accidentally. The report was adverse, but had to be disclosed.

10 Director of Public Prosecutions v A and BC Chewing Gum Ltd [1968] 1 QB 159, 165A, cited by Butler-Sloss LJ in Re M and R (Child Abuse: Evidence) [1996] 2 FLR 195, 205H.

11 See Re DH (A Minor) (Care Proceedings: Evidence and Orders) [1994] 2 FCR 3 at 43.

12 In Re CS (Expert Witnesses) [1996] 2 FLR 115, Bracewell J held that it should be a condition of appointment of any expert that he be required to hold discussions with other experts instructed in the same field of expertise in advance of the hearing in order to identify areas of agreement and dispute, which should be incorporated into a schedule for the court.

13 For example Re M (Minors) (Care Proceedings) (Child's Wishes) [1994] 1 FLR 749 .

14 Because of the disapplication of litigation privilege, the letter of instruction is not a privileged document and is invariably disclosed to the court and to the other parties.

15 The Family Division Liaison Judges are: Midland and Oxford Circuit $\mathrm{Mr}$ Justice Stuart-White; North Eastern Circuit Mr Justice Singer; Northern Circuit Mr Justice Wall; South Eastern Circuit Mr Justice Cazalet; Wales and Chester Circuit Mr Justice Connell; Western Circuit Mr Justice Holman; Family Division of the High Court Mrs Justice Hale. All are based at the Royal Courts of Justice, Strand, London, WC2A 2LL

16 'The law of evidence should not be subtle and difficult to understand. And fine distinctions should be only tolerated if both unavoidable and user friendly - ie easy to make'. Re M and R (Child Abuse: Evidence) [1996] 2 FLR 195, 211 per Butler-Sloss LJ.

\title{
Qualitative research methods in interventions in injury
}

\section{Not everything that counts can be counted}

Injury is the major cause of death in childhood in the UK and other industrialised nations. ${ }^{1}$ Moreover injury makes a considerable contribution to short and long term morbidity in children, and fear of injury to their children is one of many contributors to anxiety in parents. Injury is costly both to the NHS, and to the children and families concerned, and while there have been considerable advances in secondary and tertiary care in this area, injury prevention in childhood remains largely unevaluated in terms of its effectiveness. ${ }^{2}$ In other words, we know very little about what works in reducing child accidents. The majority of meaningful data we have on injuries in children are based on the sequelae of accidents. What was the injury? What were the consequences? What was the treatment? Data like these, while important, are unlikely to generate the kinds of information we need to prevent accidents.

In order to develop effective interventions for the prevention of injury to children, we need a better understanding of the antecedents of accidents, the environments in which injuries are produced, and the behaviours - of planners, architects, drivers and others, as well as of children and parents - which make accidents more likely.

Some of the work needed to do this will be quantitative, and recent studies in paediatric epidemiology usefully address issues such as exposure to risk, and meaningful denominators. ${ }^{3}{ }^{4}$ But not everything that counts can be counted. A good deal of data are needed in order to develop and maintain effective interventions in child injury prevention, which can only be collected through careful qualitative investigation.

The preferred medical term in this area is 'injury' rather than 'accident', however, for the purposes of this note, the term accident is preferred. This is because it is both more meaningful to children and parents, and because it encompasses those events that do not necessarily result in an injury brought to the attention of the medical profession, but which involve risk and danger. Not all accidents or unsafe behaviours result in injury, even if the sequence of events is similar. While in potentially high risk activities such as aviation and anaesthetics, data are collected on averted accidents, and used in the prevention of future disasters, we are less inclined to do this on a systematic basis for child accidents (though every child and parent uses this empirical method themself).

\section{The need for qualitative data in effective injury prevention}

The relationship between qualitative and quantitative research is not dichotomous, though it is sometimes presented as such, with qualitative data characterised as 'soft'; quantitative data as 'hard'; qualitative data as anecdotal; and quantitative as reliable and 'scientific'. An over-reverent approach to quantitative data supports the empiricist fallacy that figures are simply given objective facts, a proper understanding of which leads to one 'correct' conclusion and one conclusion only. ${ }^{5}$ The suggestion that quantitative methods are reliable but not valid, while qualitative methods are valid but not reliable overstates the case, but the lack of 'fit' between the prevention messages and the realities of keeping children safe underlie the need for an approach that combines the best of qualitative with sound quantitative methods. Without an understanding of the lives and lay expertise of those on the receiving end of our well meaning efforts, we risk ineffective, or worse, intrusive and harmful interventions, which may, for instance, raise the level of anxiety about risk while doing nothing to reduce the risk itself. A recently 
published study demonstrates an increase in the UK in socioeconomic inequality in child injury deaths. If this trend persists, the Health of the Nation's target on accidents is likely to be met for children in the non-manual classes, but not for those children from the manual classes who are those at greatest risk. ${ }^{6}$ Nothing could indicate more clearly that we have some way to go in effective prevention. Well conducted qualitative research enables us to explore why, rather than how often phenomena occur, ${ }^{7}$ and can give us an insight into what those on the receiving end of accident prevention initiatives make of them. Without this understanding, and without understanding the social worlds in which child accidents take place, we are unlikely to progress far in effective prevention.

\section{Examples of qualitative methods in exploring child accidents}

Qualitative methods, like quantitative work, can only be developed through rigorous training, and practice. Some of the methods helpful in eliciting meaningful data on child injury are described below.

FOCUS GROUP INTERVIEWS

Focus group interviews have a long history in market research, and involve bringing together a group of individuals to discuss an issue. The 'focus' means that the discussions are not entirely free ranging. Researchers develop guidelines to ensure that particular topics are covered. ${ }^{8}$ Many, perhaps most, of our values around health are developed in a social context, and it makes sense to explore issues like risk and safety in the groups that develop and maintain safety as a social value. Group interviews in a study in a disadvantaged Glasgow community indicate the relative value accorded to safety in a community where there were many pressing health and social problems. ${ }^{9}$ These interviews showed that while the medical profession may prefer the term injury, accidents and risk can be more meaningful to people for whom damp housing, poor nutrition, chronic ill health, and unemployment contributed to a seamless web of insecurity. Group interviews can also reveal a mismatch between 'official' data - a road being considered by the local authority to be relatively safe as there have been no reported deaths in the last three yearsand the reality of the road being safe as a result of self policing by the community. The road is avoided because it is so unsafe - sometimes resulting in underutilised play areas on the far side of busy roads. ${ }^{9-11}$ Interviews can show a difference in perception between professionals and parents: 'I think that the parents perceive that their road is actually very bad. But that's a perception of course. ... There is a general perception that cars are travelling faster than they actually are...If you look at the roads, and the amount they are used, and the complexity of them, they're not really that dangerous' (professional group interview). Meanwhile: 'There are too many cars...when you have parking on both sides, you can't get by...it is dangerous for the weans [children], because they go in between the motors to see if another motor is coming'.

\section{OBSERVATIONAL METHODS}

In a number of important areas in medicine, including vitamin B12 replacement, immobilisation of fractured bones, and penicillin for bacterial infections, observational studies have been sufficient to demonstrate effectiveness. ${ }^{12}$ In child accidents, very simple observational work, in some cases carried out by children, can demonstrate the ineffectiveness of some child safety 'rules'. Telling a child not to cross the road if a car is coming, or not to cross between cars is useless in most built up areas. We would rarely be able to cross the road were we to wait for these conditions. ${ }^{13}$
In a small observational study in Rochdale, children were themselves able to demonstrate the high numbers of cars going through a red or amber light, reducing the time in which the road could be safely crossed. ${ }^{11}$

STRUCTURED AND SEMISTRUCTURED INTERVIEWS

Much qualitative research is interview based. Good qualitative interviews are interactive, sensitive to the language and concepts used by the interviewee, and flexible in format. ${ }^{14}$ Interviews, built around a schedule with both 'closed' and 'open' questions can clarify why, defying the safety rules, children will sometimes be left alone. Leaving young children on their own is clearly undesirable, but interview data show the extent to which mothers frequently have to trade off one health promoting behaviour (doing the laundry, cooking) in favour of another (being alongside their children). This may cause them to leave children unsupervised rather than (for instance) carrying them down three flights of stairs while putting their washing out to dry. ${ }^{915}$ 'You can't watch them when you are in the kitchen - well obviously you don't want little children in the kitchen when you are cooking anyway'. ${ }^{9}$ Data of this kind might lead us to explore the value of day care rather than, for instance, distributing a health promotion leaflet exhorting mothers not to leave children unattended.

\section{CASE STUDIES/CRITICAL INCIDENTS}

Case studies and critical incidents are among the methods open to us in looking at the antecedents of accidents. The lack of systematic collection of data and subsequent action means that individual learning will sometimes come too late. Case studies can help us identify the point(s) at which intervention might be helpful. Examples of where this has been done (and might be done more systematically, or in small local studies), include data from coroners ${ }^{16}$ or procurator fiscals' offices, which tend to include information on the antecedents as well as the sequelae of accidents, frequently in sufficient detail to point to areas where intervention might be helpful. This method can also be applied to less serious, but commonly occurring accidents. School accident data, for instance, frequently kept routinely for insurance purposes, ${ }^{17}$ tends to detail relatively minor injuries, but using these data with children and teachers can help to identify dangerous places and risky practices. Children have a strong sense of what is, and what is not, fair. School studies have identified a sense of outrage at what car drivers do: '.. the green man was on, and I was walking across, and this car went straight through the green man, and I just moved back in time, otherwise I would have been knocked over'. ${ }^{17}$

\section{Conclusion}

We cannot understand the extent and scope of the problem of child accidents without good quantitative data. But this leaves much important data unexamined. Evaluations that record only changes in knowledge may tell us little about changes in behaviour; saturation of any area with accident prevention leaflets may give a good score on the 'Have you seen this leaflet?' question, but tell us little about reduction in risk. Even those evaluations that measure changes in accident rates (itself a difficult measure without good severity scores) may tell us little about unintended outcomes such as the anxiety that may be generated among parents during accident prevention campaigns, or the children who give up cycling rather than wear uncomfortable or expensive helmets. As mothers in a Glasgow study expressed it:

'In order to keep the kids safe, you've got them trapped in the house, you're trapped in the house, you're under more pressure, and that in itself is the cause of accidents. If 
you're going about up tae here wi' it, you're no watching your kids [and] in that space of time, something happens' and 'You get really depressed and think about all the things [safety equipment] your children should have ... ."

In the area of child accidents, we cannot hope to devise effective prevention procedures without drawing on the reservoir of local knowledge that ordinary children and adults living in unsafe communities can share with us. The really interesting question about child accidents is that given all the dangers, how do so many people manage to keep their children safe in unsafe environments? ${ }^{18}$ Only qualitative data can help us unravel this.

A good deal of work in health promotion and injury prevention assumes that a key factor in explaining accidents lies in safety education for parents. Dangerous families and dangerous people are a focus of state concern. Dangerous environments and the successful way in which, for the most part, children and adults negotiate these dangers can be accessed through careful qualitative studies at a local level. The way in which problems are recognised and defined has a crucial bearing on how policies are shaped. Qualitative work can help us reshape problems, and seek policy and practice avenues informed by the evidence of those experiencing the problem at first hand.

Policy and Development Unit,

HELEN ROBERTS

Barnardos,

Tanner's Lane, Barkingside,

Ilford, Essex IG6 1QG

I am grateful to Joe Kai, Ian Roberts, John Spencer, Erica Wimbush, and Gail Young for comments on an earlier draft of this annotation.
1 Woodroffe C, Glickman M, Barker M, Power C. Children, teenagers and health: the key data. Buckingham: Open University Press, 1993.

2 Towner E, Dowswell T, Jarvis S. The effectiveness of health promotion interventions in the prevention of unintentional childhood injury: a review of the literature. HEA policy review. London: Health Education Authority, 1993.

3 Roberts I, Norton R, Tauer B. The importance of socioeconomic and ethnic differences in exposure to risk. F Epidemiol Community Health 1996;50:1625.

4 Roberts I. Safely to school. Lancet 1996;347:1642.

5 Roberts H, ed. Women's health counts. London: Routledge, 1990:13.

6 Roberts I, Power C. Does the decline in child injury mortality vary by social class? A comparison of class specific mortality in 1981 and 1991. BMF 1996;313:784-6.

7 Mays N, Pope C, eds. Qualitative research in health care. London: BMJ Publishing Group, 1996.

8 Kitzinger J. Introducing focus groups. In: Mays N, Pope C, eds. Qualitative research in health care. London, BMJ Publications, 1996:36-45.

9 Roberts H, Smith SJ, Bryce C. Safety as a social value. Buckingham: Open University Books, 1995.

10 Hillman M, Adams J, Whitelegg J. One false move... a study of children's independent mobility. London: Policy Studies Institute, 1990.

11 McNeish D, Roberts H, Barrett A. The prevention of child accidents in Wardleworth, Rochdale. Barkingside: Barnardos, 1995.

12 Black N. Why we need observational studies to evaluate the effectiveness of health care. BMF 1996;312:1215-8.

13 Thomson JA. Child pedestrian accidents: what makes children vulnerable? In: Gillham B, Thomson JA, eds. Child safety: problem and prevention from pre-school to adolescence, London: Routledge, 1996:67-85.

14 Britten N. Qualitative interviews in medical research. In: Mays N, Pope C, eds. Qualitative research in health care. London: BMJ Publishing Group, 1996:28-35.

15 Rice C, Roberts H, Smith SJ, Bryce C. It's like teaching your child to swim in a pool full of alligators. In: Popay J, Williams G, eds. Researching the people's health. London: Routledge, 1994:115-33.

16 Levene S. Coroners' records of accidental deaths. Arch Dis Child 1991;66:1239-41.

17 Roberts H. Child accidents at home school and play. In: Gillham B, Thomson JA, eds. Child safety: problem and prevention from pre-school to adolescence. London: Routledge, 1996:40-54.

18 Roberts H, Smith SJ, Lloyd M. Safety as a social value: a community approach. In: Scott S, Williams G, Platt S, Thomas H, eds. Private risks and public dangers. Aldershot: Avebury, 1992:184-200. 